KONSTRUKTIVISME, Vol. 10, No. 2, Juli 2018

p-ISSN: 1979-9438; e-ISSN: 2442-2355

FKIP Universitas Islam Balitar, Blitar

Http://konstruktivisme.unisbablitar.ejournal.web.id; Email: konunisba@gmail.com

\title{
PENERAPAN PEMBELAJARAN PRAKTIKUM BERBASIS INKUIRI TERBIMBING UNTUK MENINGKATKAN KETRAMPILAN PROSES MAHASISWA PADA MATERI FERMENTASI
}

\author{
Dwi Kameluh Agustina ${ }^{(1)}$, Dian Puspita Anggraini ${ }^{(2)}$ \\ Prodi Pendidikan Biologi FKIP Universitas Islam Balitar Blitar \\ Jl. Majapahit No. 04 Blitar \\ E-mail: dwikameluhagustina@unisbablitar.ac.id ${ }^{1}$, \\ dianpuspitaanggraini@unisbablitar.ac.idd
}

ABSTRAK:

Penelitian ini bertujuan untuk meningkatkan ketrampilan proses mahasiswa melalui penerapan pembelajaran praktikum berbasis inkuiri terbimbing materi Fermentasi. Jenis penelitian yang digunakan penelitian tindakan kelas. dengan subyek penelitian mahasiswa yang mengikuti mata kuliah Pengantar Bioteknologi materi Fermentasi Semester Genap Tahun Akademik 2017/2018 berjumlah 25 orang mahasiswa. Teknik pengambilan data dalam bentuk observasi aktivitas dosen dan ketrampilan proses mahasiswa pada pemebelajaran praktikum berbasis inkuri terbimbing. Data dianalisis menggunakan analisis deskriptif dan kuantitatif. Hasil penelitian menunjukkan aktivitas dosen selama pembelajaran pada siklus 1 dengan nilai 61 pada kriteria cukup dan meningkat di siklus 2 dengan nilai 72 pada kriteria baik. Nilai ketuntasan klasikal pada ketrampilan proses mahasiswa di siklus 1 adalah 0\% (sangat baik), 0\% (baik), 24\% (cukup), dan 76\% (kurang baik), sedangkan pada siklus 2 adalah $0 \%$ (sangat baik), $80 \%$ (baik), $12 \%$ (cukup), dan $8 \%$ (kurang baik) bedasarkan nilai ketuntasan klasikal $80 \%$ di siklus 2 maka indikator keberhasilan telah tercapai. Pembelajaran praktikum berbasis inkuiri terbimbing mendapatkan tanggapan yang positif dari mahasiswa untuk diterapkan pada materi fermentasi. berdasarkan hasil yang diperoleh maka penerapan pembelajaran praktikum berbasis inkuiri terbimbing dapat meningkatkan ketrampilan proses mahasiswa pada materi Fermentasi ..

Kata Kunci: praktikum, inkuiri terbimbing, fermentasi

\section{PENDAHULUAN}

Materi Fermentasi pada Mata Kuliah Pengantar Bioteknologi bertujuan untuk mendapatkan pengalaman dalam mengembangkan metode ilmiah melalui pembelajaran praktikum. Menurut Titin (2013) praktikum adalah 
Dwi Kameluh Agustina ${ }^{(1)}$ Dian Puspita Anggraini ${ }^{(2)}$. 2018. Penerapan Pembelajaran Praktikum

Berbasis Inkuiri Terbimbing untuk Meningkatkan Ketrampilan Proses Mahasiswa pada Materi Fermentasi. Konstruktivisme, 10 (2): 144-153

srtategi yang membantu mahasiswa dalam belajar untuk memperoleh pengetahuan, menemukan makna, ide atau gagasan yang dilakukan secara bertahap. Praktikum mengarahkan mahasiswa dalam menggorganisasikan dan melakukn penelitian secara sistematis dengan tujuan agar mahasiswa bisa menemukan sendiri pengetahuan. Kegiatan pembelajaran praktikum berbasis inkuiri terbimbing banyak diterapkan dalam kegiatan praktikum.

Pembelajaran Inkuiri sebagai srategi menurut Sanjaya (2008) dalam Anwar dkk (2013) menyatakan bahwa kegiatan mahasiswa sebagai subjek belajar dalam mencari dan menemukan pengetahuan dan inti dari materi pelajaran. Interaktif dengan pertanyaan agar memotivasi siswa dalam menemukan sendiri jawabannya yang dapat menumbuhkan sikap percaya diri. pembelajaran inkuiri dapat mengembangkan kemampuan intelektual dengan menggunakan potensi yang dimiliki mahasiswa. Ambarsari, dkk (2013) menambahkan bahwa Inkuiri terbimbing adalah sakah satu variasi pola pembelajaran di kelas dan efektif pembelajar dapat berfikir mandiri dan saling membantu dengan teman yang lain, selain itu dapat membetuk tanggung jawab individu kelompok atau pasangannya.

Observasi yang dilakukan pada mahasiswa Pendidikan Biologi di Universitas Islam Balitar diketahui bahwa metode ilmiah dalam praktikum masih belum dimaksimalkan dalam hal menguji hipotesis melalui rancangan praktikum, pengambilan, pengolahan dan interpretasi data, serta mengkomunikasikan data secara lisan dan tertulis. Fakta pada saat observasi menunjukan dosen masih sangat dominan dalam kegiatan praktikum sehingga keaktifan mahasiswa dan ketrampilan proses dalam kegiatan tersebut sangat kurang sehingga menyebabkan mahasiswa lebih senang menerima daripada mencari atau menemukan sendiri. Konsep materi yang diterima dalam kegiatan tersebut tidak akan bertahan lama karena mahasiswa tidak banyak terlibat dalam kegiatan praktikum dan ketrampilan proses mahasiswa pada praktikum tersebut tidak terakomodasi dengan baik, menurut Sarlivanti dkk (2014), jika dibiarkan maka aka berdampak pada rendahnya hasil belajar yang diperoleh. Berdasarkan hal tersebut diperlukan kegiatan yang mendukung pembelajaran terutama pada peningkatan ketrampilan proses mahasiswa pada praktikum fermentasi. Salah satu pembelajaran praktikum yang dapat dilakukan adalah pembelajaran praktikum berbasis inkuiri terbimbing. Kegiatan praktikum berbasis inkuiri telah banyak diterapkan oleh peneliti dalam pelajaran sains Hal yang sama juga ditunjukkan oleh Mohrig (2007) dalam Sarlivanti dkk (2014) menyatakan keberhasilan penelitiannya dalam menggunakan praktikum inkuiri terbimbing dalam laboratorium kimia organik. Hasil penelitian tersebut dapat diterapkan pada materi fermentasi menggunakan pembelajaran praktikum berbasis inkuiri terbimbing untuk meningkatkan ketrampilan proses mahasiswa. 
Dwi Kameluh Agustina ${ }^{(1)}$ Dian Puspita Anggraini ${ }^{(2)}$. 2018. Penerapan Pembelajaran Praktikum Berbasis Inkuiri Terbimbing untuk Meningkatkan Ketrampilan Proses Mahasiswa pada Materi Fermentasi. Konstruktivisme, 10 (2): 144-153

\section{METODE PENELITIAN}

\section{Jenis Penelitian}

Jenis penelitian ini adalah penelitian tindakan kelas. Penelitian tindakan kelas dilakukan sebagai cara dalam memperbaiki pembelajaran (Arikunto, 2014)

\section{Waktu dan Tempat Penelitian}

Penelitian ini dilkasnakan pada semester genap tahun akademik 2017/2018. Tempat berlangsungnya penelitian ini adalah di Program Studi Pendidikan Biologi Universitas Islam Balitar Blitar.

\section{Subyek Penelitian}

Mahasiswa yang dijadikan subyek peneltian ini adalah mahasiswa yang mengikuti mata kuliah Pengantar Bioteknologi materi Fermentasi Semester Genap Tahun Akademik 2017/2018 berjumlah 25 orang mahasiswa.

\section{Prosedur Penelitian}

Prosedur penelitian tindakan kelas yang dilakukan berdasarkan Hopkins pada Arikunto (2014) meliputi 2 siklus. Tahapan pada setiap siklusnya meliputi: (1) perencanaan (Planning), (2) pelaksanaan tindakan kelas (Action), (3) Observasi (Observation) dan refleksi (reflection). Adapun rincian tahapan dari tiap siklusnya sebagai berikut:

1. Perencanaan

a. Membuat prosedur perangkat pembelajaran praktikum berbasis inkuiri terbimbing pada materi fermentasi

b. Menyusun perangkat pembelajaran materi Fermentasi yang terdiri dari; Rencana Perkuliahan Semester (RPS), Rencana Pelaksanaan Pembelajaran Semester (RPPS). kontrak perkuliahan, sumber belajar serta media pembelajaran

c. Menyusun instrumen penilaian ketrampilan proses mahasiswa melalui pembelajaran praktikum berbasis inkuiri terbimbing

d. Menentukan observer untuk mengumpulkan data dalam pelaksanaan pembelajaran.

2. Pelaksanaan 
Dwi Kameluh Agustina ${ }^{(1)}$ Dian Puspita Anggraini ${ }^{(2)}$. 2018. Penerapan Pembelajaran Praktikum Berbasis Inkuiri Terbimbing untuk Meningkatkan Ketrampilan Proses Mahasiswa pada Materi Fermentasi. Konstruktivisme, 10 (2): 144-153

Pembelajaran dilaksanakan pada 2 siklus tindakan, dalam 1 siklus terdiri dari 1 kali pertemuan, dengan tahapan sebagai berikut:

a. Melaksanakan skenario pembelajaran praktikum berbasis inkuiri terbimbing sesuai dengan perangkat pembelajaran yang telah disiapkan

b. Menilai melalui rubrik penilaian pada kegiatan mahasiswa dalam ketrampilan proses dengan indikator merumuskan hipotesis, merencanakan percobaan, melaksanakan percobaan, menafsirkan data dan berkomunikasi.

3. Observasi

Kegiatan observasi dilakukan oleh 5 orang untuk mengumpulkan data yang terdiri dari:

a. 1 orang observer mengamati aktivitas dosen dalam melaksanakan pembelajaran praktikum berbasis inkuiri terbimbing materi fermentasi.

b. 4 orang observer mengamati aktivitas mahasiswa dalam ketrampilan proses sains pada pembelajaran praktikum berbasis inkuiri terbimbing materi fermentasi.

4. Refleksi

Menganalisis temuan berupa kelemahan dan keberhasilan, penilaian dan ketercapaian tujuan penelitian pada pembelajaran praktikum berbasis inkuiri termbimbing pada materi fermentasi.

\section{Teknik Analisis Data}

a. Proses pembelajaran dosen, dianalisis dari hasil dari lembar obsevasi berdasarkan pedoman yang ada pada rubrik penilaian dengan Kategori yaitu 81-100 Amat Baik, 70-80 Baik dan $\leq 69$ Cukup.

b. Penilaiaan ketrampilan proses mahasiswa menggunakan deskriptif kuantitatif dengan menghitung prosentase ketuntasan belajar mahasiswa pada ketrampilan proses.

Ketrampilan proses mahasiswa $=\frac{\text { jumlah skor yang diperolah }}{\text { jumlah skor maksismum }} \times 100 \%$

Kriteria Ketrampilan Proses mahasiswa yaitu 0 - 40 (Kurang Baik), 41 60 (Cukup Baik), 61 - 80 (Baik) dan 81-100 (Sangat Baik). 
Dwi Kameluh Agustina ${ }^{(1)}$ Dian Puspita Anggraini ${ }^{(2)}$. 2018. Penerapan Pembelajaran Praktikum Berbasis Inkuiri Terbimbing untuk Meningkatkan Ketrampilan Proses Mahasiswa pada Materi Fermentasi. Konstruktivisme, 10 (2): 144-153

\section{Indikator Keberhasilan}

Indikator keberhasilan dalam penelitian ini adalah peningkatan aktivitas dosen dengan minimal pada kategori baik dalam pembelajaran dan ketuntasan belajar secara klasikal pada ketrampilan proses sebesar $75 \%$.

\section{HASIL DAN PEMBAHASAN}

\section{Hasil}

\section{A. Aktivitas Dosen}

Pembelajaran praktikum berbasis inkuiri terbimbing dalam pengamatan aktivitas dosen didapatkan 18 aspek yang diamati dengan jumlah skor maksimal 83 pada siklus 2, sebagaimana yang ditunjukkan pada tabel 1 berikut ini:

Tabel 1: Ketercapaian Aktivitas Dosen dalam Pembelajaran Praktikum Berbasis Inkuiri Terbimbing pada Materi Fermentasi

\begin{tabular}{lcc}
\hline $\begin{array}{l}\text { Capaian Aktivitas } \\
\text { Dosen }\end{array}$ & Siklus 1 & Siklus 2 \\
\hline Jumlah Skor & 55 & 65 \\
$\begin{array}{l}\text { Presentase (\%) } \\
\text { Kategori }\end{array}$ & 61 & 72 \\
& Cukup & Baik \\
\hline
\end{tabular}

\section{B. Ketrampilan Proses Mahasiswa}

Data Pengamatan ketrampilan proses mahasiswa dilakukan oleh peneliti dibantu oleh 4 orang observer menggunakan lembar observasi dengan hasil sebagai berikut:

Tabel 2: Pengamatan Ketrampilan Proses Mahasiswa pada Pembelajaran Praktikum Berbasis Inkuiri Terbimbing Materi Fermentasi

\begin{tabular}{|c|c|c|c|c|}
\hline \multirow[t]{2}{*}{ Kriteria } & \multicolumn{2}{|c|}{ Siklus I } & \multicolumn{2}{|c|}{ Siklus II } \\
\hline & $\begin{array}{c}\text { Frekuensi } \\
\text { (mahasiswa) }\end{array}$ & $\begin{array}{c}\text { Prosentase } \\
(\%)\end{array}$ & $\begin{array}{c}\text { Frekuensi } \\
\text { (mahasiswa) }\end{array}$ & $\begin{array}{c}\text { Prosentase } \\
(\%)\end{array}$ \\
\hline $\begin{array}{c}81-100 \\
\text { (Sangat Baik) }\end{array}$ & 0 & 0 & 0 & 0 \\
\hline $\begin{array}{l}61-80 \\
\text { (Baik) }\end{array}$ & 0 & 0 & 20 & 80 \\
\hline $\begin{array}{c}41-60 \\
\text { (Cukup Baik) }\end{array}$ & 6 & 24 & 3 & 12 \\
\hline $\begin{array}{c}0-40 \\
\text { (Kurang Baik) }\end{array}$ & 19 & 76 & 2 & 8 \\
\hline Jumlah & 25 & 100 & 9 & 100 \\
\hline
\end{tabular}


Dwi Kameluh Agustina ${ }^{(1)}$ Dian Puspita Anggraini ${ }^{(2)}$. 2018. Penerapan Pembelajaran Praktikum Berbasis Inkuiri Terbimbing untuk Meningkatkan Ketrampilan Proses Mahasiswa pada Materi Fermentasi. Konstruktivisme, 10 (2): 144-153

\section{Refleksi}

Berdasarkan data aktivitas dosen di siklus 1 masih dalam kategori cukup dan mengalami peningkatan di siklus 2 pada kategori baik. Ketrampilan proses mahasiswa pada siklus 1 masih belum memenuhi indikator keberhasilan dan pada siklus 2 telah mencapai diatas $75 \%$.

\section{BAHASAN}

1. Akitivitas Dosen

Grafik presentase aktivitas dosen pada pembelajaran praktikum berbasis inkuiri terbimbing pada siklus 1 dan 2 ditunjukkan pada gambar 1 :

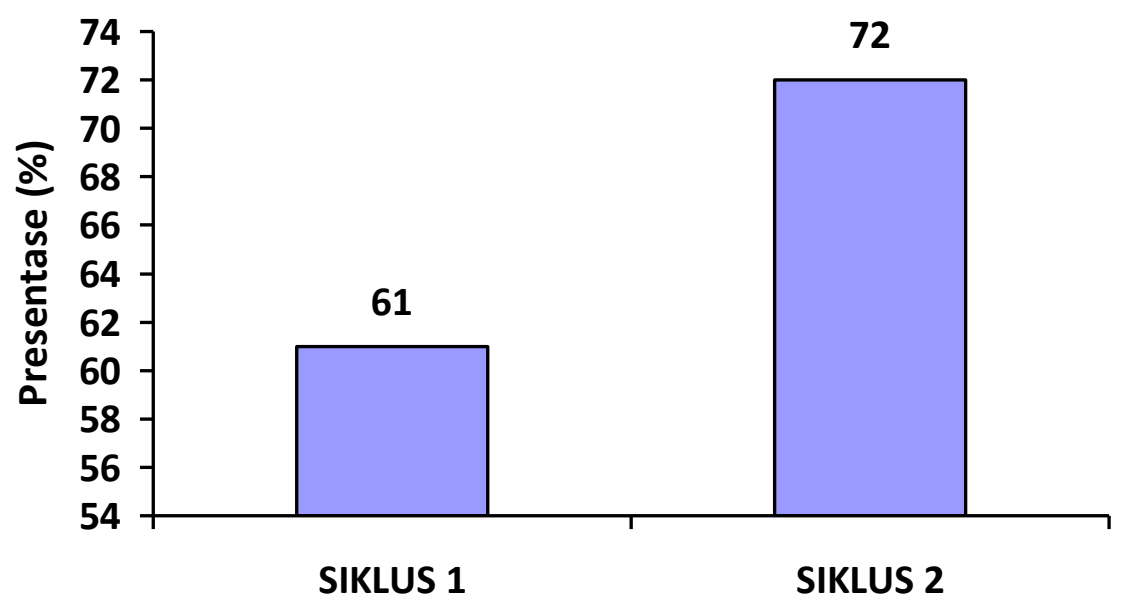

Aktivitas Dosen

Gambar 1: Presentase aktivitas dosen pada pada pembelajaran praktikum berbasis inkuiri terbimbing materi Fermentasi

Berdasarkan gambar 1 menunjukkan bahwa presentase capaian aktivitas dosen pada siklus 1 selama pembelajaran mempunyai nilai $61(\%)$ yaitu dengan kategori cukup. Hal ini terjadi karena dosen masih belum fokus terhadap materi yang diberikan. mahasiswa pada siklus 1 belum memiliki perhatian penuh terhadap dosen. dosen masih belum meminta kepada mahasiswa untuk memberikan umpan balik pembelajaran. pada siklus ini dosen masih kurang dalam berkolaborasi kepada mahasiswa tentang kegiatan praktikum yang dilaksanakan sehingga masih terpaku pada model lama, altivitas dosen cenderung dominan. Pembelajaran di siklus 2 mulai terlihat aktivitas dosen, mahasiswa mulai bisa berdaptasi dalam kegiatan peraktikum berbasis inkuiri terbimbing. Tampak mahasiswa lebih mandiri dan antusias 
Dwi Kameluh Agustina ${ }^{(1)}$ Dian Puspita Anggraini ${ }^{(2)}$. 2018. Penerapan Pembelajaran Praktikum Berbasis Inkuiri Terbimbing untuk Meningkatkan Ketrampilan Proses Mahasiswa pada Materi Fermentasi. Konstruktivisme, 10 (2): 144-153

untuk mengajukan hipotesis, mencari informasi, melakukan penyelidikan, melakukan pengamatan, mencatat dan mengolah data, serta menyajikannya dalam laporan. Menurut Aktamis dan Acar (2010), dalam Sundari, dkk (2017) pembelajaran praktikum di laboratorium dapat mengembangkan kemampuan pembelajar dalam keterampilan pengaturan diri. Pengaturan diri pada saat pembelajaran sangat penting dilakukan terutama dalam kegiatan praktikum di laboratorium, hal tersebut dapat meningkatkan prestasi belajar dan ketrampilan untuk menemukan pengetahuan secara mandiri.

2. Ketrampilan Proses Mahasiswa

Grafik presentase ketrampilan proses mahasiswa dalam melaksanakan praktikum berbasis inkuiri terbimbing ditunjukkan pada gambar 2 berikut ini:

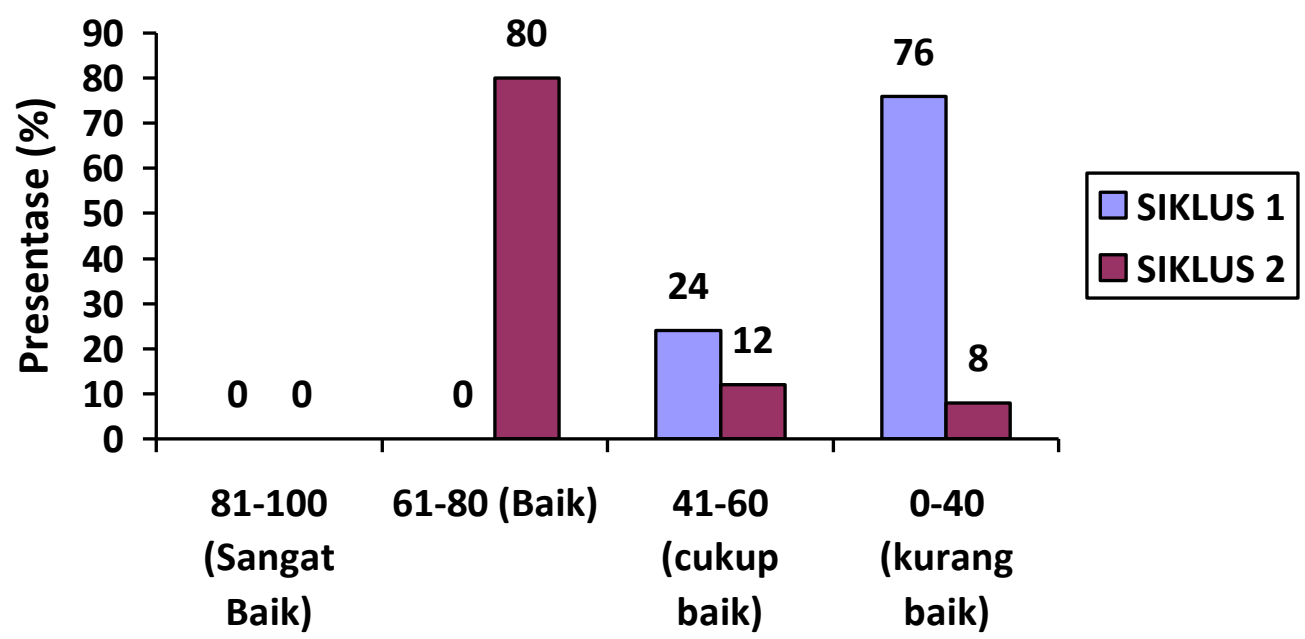

Kriteria

Gambar 2: Presentase ketrampilan proses mahasiswa pada pada pembelajaran praktikum berbasis inkuiri terbimbing materi Fermentasi

Berdasarkan gambar 2 diketahui bahwa presentase ketrampilan proses mahasiswa pada siklus 1 dengan kriteria sangat baik $0 \%$, baik $0 \%$, cukup $24 \%$, dan kurang baik $76 \%$. Pembelajaran praktikum berbasis inkuiri terbimbing pada siklus 1 masih belum berdampak pada ketuntasan secara klasikal dari ketrampilan proses mahasiswa, karena terdapat $76 \%$ (kurang baik) mahasiswa yang masih belum tuntas secara klasikal. Rendahnya ketuntasan secara klasikal yang diperoleh disebabkan oleh mahasiswa masih belum terbiasa dengan pembelajaran praktikum berbasis inkuiri. Yuhana dkk 
Dwi Kameluh Agustina ${ }^{(1)}$ Dian Puspita Anggraini ${ }^{(2)}$. 2018. Penerapan Pembelajaran Praktikum

Berbasis Inkuiri Terbimbing untuk Meningkatkan Ketrampilan Proses Mahasiswa pada Materi Fermentasi. Konstruktivisme, 10 (2): 144-153

(2017), menambahkan bahwa pola pengetahuan mahasiswa masih berupa didapat mahasiswa berupa teori yang dihapal namun mudah dilupakan. melibatkan seluruh kemampuan mahasiswa dalam memecahkan suatu selain itu mahasiswa masih lemah dalam membuat langkah-langkah sistematis pada praktikum sebagai konstruksi darii konsep pembelajaran mandiri.

Berdasarkan gambar 2 pada siklus 2 diketahui bahwa nilai ketrampilan proses mahasiswa secara klasikal pada pembelajaran praktikum berbasis inkuiri terbimbing adalah $0 \%$ sangat baik, $80 \%$ baik, $12 \%$ cukup, dan $8 \%$ kurang baik. Peningkatan ketrampilan proses mahasiswa di siklus 2 disebabkan oleh antusias dan adaptasi mahasiswa pada pembelajaran praktikum berbasis inkuiri terbimbing materi fermentasi menjadi besar, proses menemukan sendiri konsep-konsep dari pengetahuan tentang fermentasi menjadi terbangun. perilaku pengamatan, mengajukan pertanyaan sudah tampak pada masing-masing individu mahasiswa. pola-pola pengamatan tersbut digunakan mahasiswa untuk menjawab pertanyaan yang diberikan sehingga mahasiswa memiliki kemampuan menalar mahasiswa dengan baik. Titin (2013) mengungkapkan bahwa perkembangan penalaran mahasiswa sesuai dengan tahapan perkembangan kognitif dalam teori Piaget. Teori piagetyang diungkapkan adalah mahasiswa masuk ke dalam tahap operasional karena mampu berfikir abstrak serta logis menggunakan metode berpikir ilmiah.

Pekembangan kognitif mahasiswa terbangun dengan baik dalam memungumpulkan informasi-informasi baru sehingga keaadaan tersebut menjadikan pengalaman baru bagi mahasiwa dengan tahapan mengajukan perta nyaan, menyusun hipotesis, mengumpulkan dan menganalisis data yang menjadi dari bagian pembelajaran praktikum berbasis inkuiri (Rahmawati dkk, 2014). Pembelajaran praktikum berbasis inkuiri terbimbing mendapatkan respon dari mahasiswa melalui angket respon. Diketahui bahwa mahasiswa tertarik dalam pembelajaran praktikum berbasis inkuiri terbimbing. Hasil penyebaran angket didapatkan bahwa dari 25 mahasiswa, 22 mahasiswa menyatakan bahwa materi fermentasi menarik untuk diajarkan dalam praktikum, 20 mahasiswa meyatakan bahwa materi fermentasi menyenangkan diajarkan dengan pembelajaran fermentasi berbasis inkuiri terbimbing. 18 mahasiswa dari 25 mahasiswa mengetahui bahwasanya fermentasi dapat menghasilkan produk yang bernilai jual. Berdasarkan hasil wawancara dengan 25 mahasiswa menunjukkan bahwa mahasiswa memberikan tanggapan positif terhadap pembelajaran pratikum berbasis inkuiri terbimbing. Menurut Kholifudin (2012) dalam Rahmawati, dkk (2014) pembelajaran praktikum berbasis inkuiri terbimbing dapat memberikan pembelajar untuk berpartisipasi aktif dalam kegiatan pembelajaran sehingga memunculkan rasa ingin tahu serta mendorong untuk bertanya dan berpendapat. Pembelajaran inkuiri terbimbing yang dirangkaikan kegiatan praktikum di laboratorium menjadikan 
Dwi Kameluh Agustina ${ }^{(1)}$ Dian Puspita Anggraini ${ }^{(2)}$. 2018. Penerapan Pembelajaran Praktikum Berbasis Inkuiri Terbimbing untuk Meningkatkan Ketrampilan Proses Mahasiswa pada Materi Fermentasi. Konstruktivisme, 10 (2): 144-153

lebih bersemangat dan termotivasi sehingga penguasaan konsep dan penelaran mahasiswa juga meningkat. Chen dan She (2014) menmbahkan bahwa mengajukan pertanyaan ilmiah, mengontrol variabel, merencanakan suatu cara untuk menjawab pertanyaan, merancang eksperimen untuk menguji hipotesis, mengolah dan menganalisa data, dan mengiterprestasikan data merupakan kegiatan pembelajaran inkuiri yang melibatkan penalaran.

\section{SIMPULAN}

Berdasarkan hasil penelitian yang telah dilakukan dapat disimpulkan bahwa:

1. Aktivitas dosen selama pembelajaran pada siklus 1 dengan nilai 61 pada kriteria cukup dan meningkat di siklus 2 dengan nilai 72 pada kriteria baik.

2. Nilai ketuntasan klasikal pada ketrampilan proses mahasiswa di siklus 1 adalah 0\% (sangat baik), 0\% (baik), 24\% (cukup), dan 76\% (kurang baik), sedangkan pada siklus 2 adalah $0 \%$ (sangat baik), $80 \%$ (baik), $12 \%$ (cukup), dan $8 \%$ (kurang baik) bedasarkan nilai ketuntasan klasikal $80 \%$ di siklus 2 maka indikator keberhasilan telah tercapai.

3. Pembelajaran praktikum berbasis inkuiri terbimbing mendapatkan tanggapan yang positif dari mahasiswa untuk diterapkan pada materi fermentasi.

\section{SARAN}

Pembelajaran praktikum berbasis inkuiri terbimbing dapat dilanjutkan dengan penelitianpada materi lain di mata kuliah pengantar bioteknologi.

\section{DAFTAR RUJUKAN}

Ambarsari, W. Santosa, S. Maridi. 2013. Penerapan Pembelajaran Inkuiri Terbimbing terhadap Keterampilan Proses Sains Dasar pada Pelajaran Biologi Siswa Kelas VIII SMP Negeri 7 Surakarta. Pendidikan Biologi. 5(1):81-95.

Anwar, Abdullah, dan Apriana, E. Penerapan Problem Based Learning Dan Inkuiri Untuk Meningkatkan Kemampuan Berpikir Kritis Dan Sikap Kepedulian Lingkungan Mahasiswa Fakultas Kesehatan Masyarakat Universitas Muhammadiyah Aceh. Jurnal EduBio Tropik. 2(2) :187-250. 
Dwi Kameluh Agustina ${ }^{(1)}$ Dian Puspita Anggraini ${ }^{(2)}$. 2018. Penerapan Pembelajaran Praktikum Berbasis Inkuiri Terbimbing untuk Meningkatkan Ketrampilan Proses Mahasiswa pada Materi Fermentasi. Konstruktivisme, 10 (2): 144-153

Arikunto, S. 2014. Prosedur Penelitian Suatu Pendekatan Praktik. Jakarta: Rineka Cipta.

Chen, C,T \& She, H.C. 2014. The Effectiveness of Scientific Inquiry with/without Integration of Scientific Reasoning. International Journal of Science and Mathematics Education.

Rahmawati, R. Haryani, S dan Kasmui. 2014. Penerapan Praktikum Berbasis Inkuiri untuk Meningkatkan Keterampilan Proses Sains Siswa. Jurnal Inovasi Pendidikan Kimia. 8(2):1390-1397.

Sarlivanti, Adlim, Djailani. 2014. Pembelajaran Praktikum Berbasis Inkuiri Terbimbing untuk Meningkatkan Keterampilan Berpikir Kritis dan Keterampilan Proses Sains pada Pokok Bahasan Larutan Penyangga. Jurnal Pendidikan Sains Indonesia. 2 (1): 75-86.

Sundari. T, Pursitasari, I.D, dan Heliawati, L. 2017. Pembelajaran Inkuiri Terbimbing Berbasis Praktikum pada Topik Laju Reaksi. Pendidikan Sains Pascasarjana Universitas Negeri Surabaya. 6(2):1340-1347.

Titin. 2013. Deskripsi Keterampilan Proses Sains Mahasiswa Pendidikan Biologi Melalui Pembelajaran Berbasis Praktikum pada Mata Kuliah Taksonomi Tumbuhan. Jurnal Pendidikan Matematika dan IPA. 4(1):47-52.

Yuhanna, W. L, Retno, R.S, dan Juwanita. 2017. Implementasi Pembelajaran "Inquiry Small Research" untuk Meningkatkan Sikap IImiah dan Prestasi Belajar Mahasiswa Pendidikan Biologi. Bioilmi. 3(2):7177. 